\title{
Optimizing near Infrared Reflectance Spectroscopy to Predict Nutritional Quality of Chickpea Straw for Livestock Feeding
}

\author{
Tena Alemu ${ }^{1, *}$, Jane Wamatu ${ }^{2}$, Adugna Tolera ${ }^{1}$, Mohammed Beyan ${ }^{1}$, Million Eshete ${ }^{3}$, Ashraf Alkhtib ${ }^{4}$ iD \\ and Barbara Rischkowsky ${ }^{2}$
}

check for updates

Citation: Alemu, T.; Wamatu, J.; Tolera, A.; Beyan, M.; Eshete, M.; Alkhtib, A.; Rischkowsky, B. Optimizing near Infrared Reflectance Spectroscopy to Predict Nutritional Quality of Chickpea Straw for Livestock Feeding. Animals 2021, 11, 3409. https://doi.org/10.3390/ ani11123409

Academic Editors: Sonia Tassone and Pier Giorgio Peiretti

Received: 10 November 2021 Accepted: 27 November 2021 Published: 29 November 2021

Publisher's Note: MDPI stays neutral with regard to jurisdictional claims in published maps and institutional affiliations.

Copyright: (c) 2021 by the authors. Licensee MDPI, Basel, Switzerland. This article is an open access article distributed under the terms and conditions of the Creative Commons Attribution (CC BY) license (https:/ / creativecommons.org/licenses/by/ $4.0 /)$.
1 Department of Animal and Range Sciences, Hawassa College of Agriculture, Hawassa University, Hawassa P.O. Box 5, Ethiopia; atolera@yahoo.com (A.T.); mohadbeyan@yahoo.com (M.B.)

2 International Centre for Agricultural Research in Dry Areas, Addis Ababa P.O. Box 5689, Ethiopia; J.Wamatu@cgiar.org (J.W.); b.rischkowsky@cgiar.org (B.R.)

3 Department of Plant Science/Plant Breeding, Ethiopian Institute of Agricultural Research, Addis Ababa P.O. Box 2003, Ethiopia; million102001@yahoo.com

4 School of Animal, Rural and Environmental Sciences, Nottingham Trent University, Brackenhurst Campus, Southwell, Nottinghamshire NG25 0QF, UK; a.s.alkhtib@gmail.com

* Correspondence: tena_alemu@yahoo.com

Simple Summary: The potential of near infrared reflectance spectroscopy (NIRS) to predict the nutritive value of chickpea straw was identified. Spectral data of 480 samples of chickpea straw (40 genotypes) were scanned with a spectral range of 1108 to $2492 \mathrm{~nm}$. The samples were reduced to 190 representative samples based on the spectral data then divided into a calibration set (160 samples) and a cross-validation set (30 samples). All 190 samples were analysed for dry matter, ash, crude protein, neutral detergent fibre, acid detergent fibre, acid detergent lignin, $\mathrm{Zn}, \mathrm{Mn}, \mathrm{Ca}, \mathrm{Mg}, \mathrm{Fe}$, $\mathrm{P}$, and in vitro gas production metabolizable energy using conventional methods. The prediction equations were generated by multiple regression analysis. The NIRS prediction equations in the study accurately predicted the nutritive value of chickpea straw $\left(R^{2}\right.$ of cross validation $>0.68$; standard error of prediction $<1 \%$ ). Chickpea straw nutritive value could be predicted using NIRS.

Abstract: Multidimensional improvement programs of chickpea require screening of a large number of genotypes for straw nutritive value. The ability of near infrared reflectance spectroscopy (NIRS) to determine the nutritive value of chickpea straw was identified in the current study. A total of 480 samples of chickpea straw representing a nation-wide range of environments and genotypic diversity (40 genotypes) were scanned at a spectral range of 1108 to $2492 \mathrm{~nm}$. The samples were reduced to 190 representative samples based on the spectral data then divided into a calibration set (160 samples) and a cross-validation set (30 samples). All 190 samples were analysed for dry matter, ash, crude protein, neutral detergent fibre, acid detergent fibre, acid detergent lignin, $\mathrm{Zn}, \mathrm{Mn}, \mathrm{Ca}, \mathrm{Mg}, \mathrm{Fe}, \mathrm{P}$, and in vitro gas production metabolizable energy using conventional methods. Multiple regression analysis was used to build the prediction equations. The prediction equation generated by the study accurately predicted the nutritive value of chickpea straw $\left(R^{2}\right.$ of cross validation $>0.68$; standard error of prediction $<1 \%$ ). Breeding programs targeting improving food-feed traits of chickpea could use NIRS as a fast, cheap, and reliable tool to screen genotypes for straw nutritional quality.

Keywords: calibration; validation; prediction error; nutritional quality; crop residue; NIRS

\section{Introduction}

Chickpea is one of the key pulses in the world [1]. Cultivated chickpeas are categorized into two main groups: Desi and Kabuli [1]. Desi grains are small, dark in colour, and smooth or wrinkled and are preferred for use as flour [1]; however, they are used for direct cooking. Kabuli grains are large and cream in colour and contain less fibre than Desi grains. Thus, Kabuli grains are used for whole grain cooking [1]. The world yield of chickpea grains 
was $14,246,000 \mathrm{t}$ in 2019 , which accounts for $12 \%$ of the world pulse grain. Chickpea grains have high levels of protein, minerals, and vitamins for human consumption [1]. Moreover, growing chickpea improves soil fertility, land use intensity, and provides households with cash supply [2]. It has been reported that the production of $1 \mathrm{~kg}$ of chickpea grains is associated with production of $1.55 \mathrm{~kg}$ of straw [3]. Accordingly, chickpea cultivation generates large amounts of straw $(\sim 221,001,000 \mathrm{t})$, which is used for ruminant feeding. Chickpea straw contains $65 \mathrm{~g} / \mathrm{kg}$ of crude protein (CP), $694 \mathrm{~g} / \mathrm{kg}$ of neutral detergent fibre (NDF), $516 \mathrm{~g} / \mathrm{kg}$ of acid detergent fibre, $111 \mathrm{~g} / \mathrm{kg}$ of acid detergent lignin, and 7.7 MJ/kg of metabolizable energy [1]. Chickpea straw has a high content of antinutritional factors like tannins and oxalates [1].Yet, ruminant animals were reported to have a high tolerance to tannins and oxalates if the diet was adequately supplemented with protein and energy [1]. Chickpea straw is also used as soil mulch in mixed farming systems [4]. Accordingly, leveraging grain yield alongside straw yield and nutritive value will improve the biomass supply for human and livestock consumption and will trigger greater use of cereal straw for soil mulching [4]. Varietal selection to increase the yield and nutritive value of chickpea straw is promising $[3,5,6]$. The improvement programme of chickpea leaded by the International Centre of Agricultural Research in the Dry Areas (ICARDA) and national research centres in developing countries started recently to recognize the importance of chickpea straw's nutritive value and started to include it as a selection criterion in their breeding programs. These programs are expected to produce large sets of chickpea straw samples to be analysed for nutritional value [7]. The conventional methods of feed evaluation cannot cope with this huge number of samples since they are expensive and time consuming. The near infrared spectroscopy (NIRS) technique has been applied for the nutritional characteristics of animal feeds [8,9]. Unlike most conventional analytical methods, the NIRS technique is fast, low-cost, and nondestructive to the sample. Additionally, NIRS requires very little sample preparation and no chemicals [10]. It is consistent, accurate, and fast [10]. Furthermore, NIRS can be used to analyse multiple feed nutrient properties at one time [8]. Generally used as a quantitative and qualitative analysis method, NIRS technology requires the development of prediction models, which involves multivariate analysis and analytical chemistry to extract the most relevant information [10]. The ability of NIRS technology to determine the nutritive value of chickpea straw was evaluated by Dereje et al. [11]. Yet, the application of the results of this study is limited because the number of chickpea samples was marginal and the genotypic and locational characters of the samples were unknown.

Developing NIRS equations for chickpea straw nutritional analysis would facilitate the process of chickpea improvement for food and feed production, which would promote sustainable food production in mixed farming systems. Although the reliability of NIRS has been well investigated for temperate feeds, no studies have reported on the feasibility of the use of NIRS to determine the nutritive value of chickpea straw. Thus, the goal of the current study is to determine the accuracy and robustness of NIRS to determine the nutritive value of chickpea straw for screening the genotype in multi-dimensional improvement programs.

\section{Materials and Methods}

\subsection{Sample Description and Experimental Layout}

A total of 480 samples of chickpea straw from preliminary and national variety trials were used in the current study. The description of the sampling areas is presented in Table 1 . The straw samples were collected after harvest, naturally dried for 7 days, and then stored in paper bags until they were analysed. 
Table 1. Description of the experimental sites.

\begin{tabular}{|c|c|c|c|c|c|}
\hline \multirow{2}{*}{ Characteristics } & \multicolumn{5}{|c|}{ Locations } \\
\hline & Akaki & Alem Tena & Chefe Donsa & Debre-Zeit & Minjar \\
\hline Altitude (masl) & 2200 & 1575 & 2450 & 1900 & 1810 \\
\hline Latitude & $08^{\circ} 53$ & $08^{\circ} 18$ & $08^{\circ} 57$ & $08^{\circ} 44$ & $08^{\circ} 55$ \\
\hline Longitude & $38^{\circ} 49$ & $38^{\circ} 57$ & $39^{\circ} 06$ & $38^{\circ} 58$ & $39^{\circ} 45$ \\
\hline Max temperature & 26.5 & 29.8 & 26 & 28.3 & 28 \\
\hline Min temperature & 7 & 12.9 & 7 & 8.9 & 10 \\
\hline Rainfall (mm) & 1025 & 728 & 843 & 851 & 867 \\
\hline $\begin{array}{c}\text { Rainfall } \\
\text { distribution }\end{array}$ & Bimodal & Erratic & Bimodal & Bimodal & bimodal \\
\hline Soil type & Vertisols & Light & Vertisols & Vertisols & Light \\
\hline $\begin{array}{l}\mathrm{n} \text { of Desi } \\
\text { genotypes }\end{array}$ & 14 & 13 & 14 & 14 & 0 \\
\hline $\begin{array}{l}\mathrm{n} \text { of Kabuli } \\
\text { genotypes }\end{array}$ & 13 & 0 & 13 & 26 & 13 \\
\hline $\mathrm{n}$ of genotypes & 27 & 13 & 27 & 40 & 13 \\
\hline Sn of samples & 108 & 52 & 108 & 160 & 52 \\
\hline
\end{tabular}

\subsection{Spectral Analysis of Chickpea Straw Samples}

All samples were ground ( $1 \mathrm{~mm}$ sieve size), dried at $60{ }^{\circ} \mathrm{C}$ overnight in an oven to standardize the moisture content, and then scanned using Foss NIRS 5000 with software package WinISI II in a spectral range of 1108 to $2492 \mathrm{~nm}$ (Win Scan version 1.5, 2000, intrasoft international, L.L.C, Luxembourg). Optical values were recorded as $\log 1 /$ Reflectance.

\subsection{Chemical Analysis Using Conventional Methods}

In total, 190 samples were subsampled out of the 480 samples using the CENTRE algorithm based on NIRS spectra data [12]. The samples were analysed for dry matter (DM), ash, and crude protein (CP) according to the methodology of AOAC [13]. The sample was ashed in a muffle furnace at $500{ }^{\circ} \mathrm{C}$ overnight (method 942.05) to determine the ash content. The Kjeldahl method using Kjeldahl (protein/nitrogen) Model 1026 (Foss Technology Corp., Hilleroed, Denmark) was used to identify the level of nitrogen of the sample (method 954.01). The nitrogen content was converted to crude protein by a conversion factor of 6.25. Van Soest et al. [14] was used to determine the NDF and ADF content. Neutral detergent fibre and ADF were expressed exclusive of residual ash. Neutral detergent fibre analysis did not include a heat-stable amylase. The lignin content of the sample was analysed by solubilisation of cellulose with sulphuric acid. Metabolizable energy was measured in rumen microbial inoculum using the in vitro gas production method. The in vitro gas production method ([15]) was used to prepare the buffer solution. Rumen fluid was obtained before morning feeding using a vacuum pump from three ruminally cannulated cows. The cows were fed grass hay $(790 \mathrm{~g} / \mathrm{kg})$, wheat bran $(203 \mathrm{~g} / \mathrm{kg})$, salt $(3.2 \mathrm{~g} / \mathrm{kg})$, and a mineral and vitamin mixture $(4.6 \mathrm{~g} / \mathrm{kg})$. Handling of the cows and rumen fluid sampling was approved by the Environmental and Occupational Health and Safety unit of International Livestock Research Institute. Fluids were composited $(1: 1, v / v)$, filtered through four layers of cheesecloth, and added to the buffer solution $(1: 2, v / v)$, which was kept in a water bath at $39{ }^{\circ} \mathrm{C}$ under continuous $\mathrm{CO} 2$ flushing. The buffered rumen fluid $(30 \mathrm{~mL})$ was transferred into $100 \mathrm{~mL}$ syringes containing $0.2 \mathrm{~g}$ of straw sample and immediately placed into a water bath at $39^{\circ} \mathrm{C}$. The $24 \mathrm{~h}$ gas production was recorded and used to calculate ME according to Menke and Steingass [16]. Phosphorous, calcium, magnesium, manganese, iron, and zinc contents were determined by an atomic absorption spectrophotometer (A. Analyst 300, Perkin Elmer, Shelton, CT, USA). 


\subsection{Statistical Analysis}

The spectral data were not subjected to any mathematical treatment. The CENTRE algorithm was used to calculate the GH value (Mahalanobis global distance to the centre of the population) of each sample. Samples with GH $\geq 3$ were considered as outliers. No outliers were found in the data; thus, all 190 samples were divided into two groups: a calibration group (160 samples) and a cross-validation group (30 samples). Multiple regression analysis was used to build the equations using the calibration group. The chemical composition of the validation set was predicted using the prediction equations and then the standard error of prediction was calculated (SEP). Calibration equations were evaluated using the coefficient of determination $\left(R^{2}\right)$, standard error of calibration (SEC), and SEP. Statistical analysis of the data was performed using WinISI II software.

\section{Results}

The means and standard deviation of the chemical composition, mineral analyses, and ME of chickpea and straw for both predicted and reference samples are presented in Table 2. There was wide variation in the chemical composition and ME of chickpea samples, which cover most of the variability reported in the literature.

Table 2. Characterization of the data sets used to generate the prediction equation of chickpea straw.

\begin{tabular}{|c|c|c|c|c|}
\hline \multirow{2}{*}{ Nutritional Composition } & Reference & \multirow{2}{*}{ SD } & NIRS & \multirow{2}{*}{ SD } \\
\hline & Mean & & Mean & \\
\hline $\mathrm{DM}(\%)$ & 90.40 & 0.47 & 90.41 & 0.39 \\
\hline Ash (\%) & 9.01 & 2.02 & 9.01 & 1.93 \\
\hline $\mathrm{CP}(\%)$ & 6.04 & 3.44 & 6.01 & 3.39 \\
\hline $\operatorname{NDF}(\%)$ & 53.75 & 8.64 & 53.79 & 8.6 \\
\hline ADF (\%) & 39.66 & 7.03 & 39.6 & 6.97 \\
\hline ADL $(\%)$ & 9.13 & 1.82 & 9.13 & 1.77 \\
\hline ME (MJ/Kg DM) & 7.86 & 0.88 & 7.88 & 0.87 \\
\hline \multicolumn{5}{|l|}{ Mineral composition } \\
\hline $\mathrm{Zn}(\mathrm{mg} / \mathrm{kg})$ & 12.87 & 7.41 & 12.98 & 6.95 \\
\hline $\mathrm{Mn}(\mathrm{mg} / \mathrm{kg})$ & 70.54 & 44.4 & 70.11 & 42.1 \\
\hline $\mathrm{Ca}(\mathrm{g} / \mathrm{kg})$ & 13.52 & 3.72 & 13.47 & 3.29 \\
\hline $\operatorname{Mg}(\mathrm{g} / \mathrm{kg})$ & 2.01 & 0.43 & 2.02 & 0.39 \\
\hline $\mathrm{Fe}(\mathrm{mg} / \mathrm{kg})$ & 685 & 741 & 675 & 691 \\
\hline $\mathrm{P}(\mathrm{g} / \mathrm{kg})$ & 0.89 & 0.71 & 0.82 & 0.54 \\
\hline
\end{tabular}

SD: standard deviation; DM: dry matter; CP: crude protein, NDF: neutral detergent fibre, ADF: acid detergent fibre; ADL: Acid detergent lignin; ME: in vitro gas production metabolizable energy.

\subsection{Calibration}

Results of the NIRS calibration are presented in Table 3. The $R^{2} c$ of the chickpea straw's chemical composition ranged from 0.84 in DM to 0.99 in ADL. The $R^{2} c$ of Me was high (0.99). $\mathrm{R}^{2} \mathrm{c} \mathrm{Zn}, \mathrm{Ca}, \mathrm{Fe}, \mathrm{Mn} \mathrm{Mg}$, and P ranged from 0.71 to 0.93 . The SEC of the proximate analysis ranged from $0.19 \%$ in DM to $0.85 \%$ in NDF. The SEC of ME was relatively small $(0.06 \mathrm{MJ} / \mathrm{kg} \mathrm{DM})$ and the SEC of the mineral composition of chickpea straw ranged between $0.33 \%$ and $1.92 \%$.

\subsection{Validation}

The results of the NIRS equations validation are shown in Table $3 . \mathrm{R}^{2} \mathrm{v}$ of the $\mathrm{CP}, \mathrm{NDF}$, $\mathrm{ADF}, \mathrm{ADL}$, and ME was higher than 0.96. Although, DM had a lower $\mathrm{R}^{2} \mathrm{v}$ of 0.78 . The mineral composition of chickpea straw had a high $R^{2} v$ ranging between 0.68 and 0.92 . The SEP of the proximate analysis and ME of chickpea straw ranged from $0.036 \%$ to $1.3 \%$. The SEP of the mineral composition of chickpea straw $\mathrm{Zn}, \mathrm{Ca}, \mathrm{Mg}, \mathrm{Mn}, \mathrm{Fe}$, and $\mathrm{P}$ was less than $3 \%$. 
Table 3. Values obtained from the NIRS calibration and validation of chickpea straw.

\begin{tabular}{|c|c|c|c|c|}
\hline \multirow{2}{*}{ Nutritional Composition } & Calibration & \multirow{2}{*}{ SEC (\%) } & Validation & \multirow{2}{*}{ SEP (\%) } \\
\hline & $\mathbf{R}^{2} \mathrm{c}$ & & $\mathbf{R}^{2} \mathbf{v}$ & \\
\hline DM & 0.84 & 0.19 & 0.78 & 0.24 \\
\hline Ash & 0.97 & 0.35 & 0.96 & 0.56 \\
\hline $\mathrm{CP}$ & 0.99 & 0.21 & 0.99 & 0.425 \\
\hline NDF & 0.99 & 0.85 & 0.99 & 1.3 \\
\hline $\mathrm{ADF}$ & 0.99 & 0.64 & 0.99 & 1.09 \\
\hline ADL & 0.99 & 0.22 & 0.98 & 0.36 \\
\hline ME & 0.99 & 0.06 & 0.99 & 0.036 \\
\hline \multicolumn{5}{|l|}{ Mineral composition } \\
\hline $\mathrm{Zn}$ & 0.93 & 1.89 & 0.91 & 2.27 \\
\hline $\mathrm{Mn}$ & 0.89 & 1.2 & 0.89 & 1.46 \\
\hline $\mathrm{Ca}$ & 0.91 & 1.07 & 0.89 & 1.66 \\
\hline $\mathrm{Mg}$ & 0.88 & 0.15 & 0.84 & 0.16 \\
\hline $\mathrm{Fe}$ & 0.92 & 1.92 & 0.92 & 2.08 \\
\hline $\mathrm{P}$ & 0.71 & 0.33 & 0.68 & 0.45 \\
\hline
\end{tabular}

$\mathrm{R}^{2} \mathrm{c}$ : coefficient of determination of calibration; SEC: standard error of calibration; $\mathrm{R}^{2} \mathrm{v}$ : coefficient of determination of validation; SEP: standard error of prediction; DM: dry matter; CP: crude protein, NDF: neutral detergent fibre; ADF: acid detergent fibre; ADL: Acid detergent lignin; ME: in vitro gas production metabolizable energy.

\section{Discussion}

Improved varieties of chickpea produce significantly higher yields of grains compared to the local genotypes. They have high tolerance to drought and disease [17]. Thus, adopting these varieties would enhance the food security of developing countries and improve the livelihoods of farmers relying on chickpea production. National and international research centres have recognised that many improved varieties of crops are rejected by farmers in mixed farming systems due to the low palatability and nutritive value of straw $[18,19]$. This is a huge threat to the agricultural production and food security of a large number of households in mixed farming systems. Accordingly, straw's nutritive value as a livestock feed became a priority in crop breeding programs to raise the rate of adoption of the improved varieties on the one hand and to enhance the nutritive value of the straw for livestock feeding on the other hand. Chickpea breeding programs generate huge sets of samples requiring screening for nutritive value in a short time [7]. Under such a scenario, conventional lab methods are not feasible as they are expensive, time consuming, and environmentally destructive. Here, NIRS offers a cheap, fast, and reliable method to accurately determine the nutritive value of a range of animal feed [20]. Furthermore, NIRS technology for feed analysis does not include dealing with any chemicals and does not have any animal welfare issue related to ruminal cannulation.

$R^{2} \mathrm{C}$ and $\mathrm{R}^{2} \mathrm{v}$ of the chemical composition of chickpea straw were 0.78 for DM and higher than 0.96 for ash, CP, NDF, ADF, and ADL. This indicates a high match between the NIRS spectral data and conventional lab data of DM, ash, CP, NDF, ADF, and ADL of chickpea samples. In addition to this, SEC and SEP of NIRS equations for proximate analysis and cell wall constituents of chickpea straw were lower than $1 \%$. Thus, these NIRS equations could predict the chemical composition of chickpea straw using spectral data. This is in agreement with previous studies, which reported that NIRS is an accurate method to predict the nutritive value of a range of animal feed [21-26].

$R^{2} \mathrm{C}$ and $R^{2} v$ of ME of chickpea straw were high (0.99), indicating a strong correlation between the spectral data and in vitro ME data. The NIRS prediction equation of ME had low SEC and SEP $(<0.1 \%)$. Therefore, the NIRS model produced from the current study is accurate in determining ME of chickpea straw samples. This is in agreement with results in the literature, which reported on the possibility of predicting some biological parameters including digestibility and ruminal gas production of feed using their spectral data ([22,26], respectively). Theoretically, the mineral composition of feed is not detectable by NIRS because their structure does not have organic bonds. However, minerals can be predicted 
if they are included in organic complexes [27] or due to the change that minerals cause in the water region of the spectrum [27-29]. The mineral composition of chickpea straw included in the current study had high $\mathrm{R}^{2} \mathrm{c}$ and $\mathrm{R}^{2} \mathrm{v}$. Accordingly, the association between the spectral data and mineral composition of chickpea straw is high. Furthermore, both SEC and SEP were low $(<1 \%)$. Therefore, the mineral composition of chickpea straw could be accurately predicted via the NIRS models generated by the current study. This is in disagreement with Goi et al.'s [30] study on the mineral composition of dog food, where $\mathrm{Ca}, \mathrm{P}, \mathrm{Na}$, and $\mathrm{Mg}$ were poorly predicted using the NIRS equations. On the contrary, $\mathrm{K}$ and $\mathrm{Na}$ were accurately predicted using NIRS data [30]. Furthermore, minerals were predicted from NIRS data with low error in cheese ( $\mathrm{Ca}, \mathrm{P}, \mathrm{S}, \mathrm{Mg}$, $\mathrm{Zn}$, and $\mathrm{Cu}$ [31]; $\mathrm{Na}$ and $\mathrm{K}$ [32]), meat ( $\mathrm{Ca}$ and $\mathrm{Zn} \mathrm{[33]),} \mathrm{and} \mathrm{processed} \mathrm{meat} \mathrm{products} \mathrm{(Na} \mathrm{[34-36]).} \mathrm{This} \mathrm{could} \mathrm{be} \mathrm{because}$ most of the minerals in chickpea straw might be linked to oxalate in a form of oxalate salts or they are bound to other organic compounds. Near infrared reflectance spectroscopy could be used to facilitate chickpea breeding programs for food-feed improvement by offering an accurate, cheap, and fast tool for nutritional value determination.

\section{Conclusions}

Stationary NIRS is a feasible replacement technology to the conventional nutritional analyses to determine the chemical composition, $\mathrm{ME}$, and mineral content $(\mathrm{Zn}, \mathrm{Ca}, \mathrm{Mg}, \mathrm{Mn}$, $\mathrm{Fe}$, and $\mathrm{P}$ ) of chickpea straw. This would decrease the cost (as it requires only technician time and cost of sample processing) and time of the analysis and environmental hazard associated with the conventional nutritional analysis methods. Chickpea breeders can screen chickpea genotypes for straw nutritive value using NIRS when chickpea programs target improving food and feed traits. These programs would release chickpea genotypes that are superior in grain yield and straw nutritive value, leading to more sustainable food production and food security in mixed farming systems.

Author Contributions: J.W., T.A., A.T., M.B., M.E., B.R. and A.A. conceived the study. J.W., T.A., A.T., M.B. and M.E. designed the experiment. J.W. and A.T. directed the study. T.A. Statistically analysed the data. Data were interpreted by all coauthors. All coauthors wrote and edited and revised the manuscript. All authors have read and agreed to the published version of the manuscript.

Funding: The study received financial support from the CGIAR Collaborative Research Program (CRP).

Institutional Review Board Statement: Handling of the cows and rumen fluid sampling was approved by the Environmental and Occupational Health and Safety unit of International Livestock Research Institute.

Data Availability Statement: The data presented in this study are available on reasonable request from the corresponding author.

Acknowledgments: The authors would like to acknowledge the financial support from the CGIAR Collaborative Research Program (CRP) Livestock, Ethiopian Institute of Agricultural Institute, Ethiopia for facilitating the cultivation of chickpea varieties. Appreciation goes to the Animal Nutrition Laboratory of the International Livestock Research Institute (ILRI) in Addis Ababa, Ethiopia for the analysis of the samples.

Conflicts of Interest: The authors declare no conflict of interest related to the current study.

\section{References}

1. Bampidis, V.A.; Christodoulou, V. Chickpeas (Cicer arietinum L.) in animal nutrition: A review. Anim. Feed Sci. Technol. 2011, 168, 1-20. [CrossRef]

2. Kassie, M.; Shiferaw, B.; Asfaw, S.; Abate, T.; Muricho, G.; Ferede, S.; Assefa, K. Current Situation and Future Outlooks of the Chickpea Sub-Sector in Ethiopia. 2009, pp. 3-16. Available online: http:/ / www.icrisat.org/TropicalLegumesII/pdfs/Current_ Situation.pdf (accessed on 25 November 2021).

3. Wamatu, J.; Alemu, T.; Tolera, A.; Beyan, M.; Alkhtib, A.; Eshete, M.; Ahmed, S.; Rischkowsky, B. Selecting for food-feed traits in desi and kabuli genotypes of chickpea (Cicer arietinum). J. Exp. Biol. Agric. Sci. 2017, 5, 852-860. [CrossRef] 
4. Alkhtib, A.; Wamatu, J.; Kassie, G.; Rischkowsky, B. Analysis of crop residue use in small holder mixed farms in Ethiopia. Renew. Agric. Food Syst. 2017, 32, 454-462. [CrossRef]

5. Alkhtib, A.; Wamatu, J.; Ejeta, T.; Rischkowsky, B. Genetic Variability in Food and Feed Traits of Early Maturing Desi Chickpea (Cicer arietinum) for Multi-Dimensional Improvement. Anim. Nutr. Feed Technol. 2018, 18, 389-398. [CrossRef]

6. Kafilzadeh, F.; Maleki, E. Chemical composition, in vitro digestibility and gas production of straws from different varieties and accessions of chickpea. J. Anim. Physiol. Anim. Nutr. 2012, 96, 111-118. [CrossRef] [PubMed]

7. Sharma, K.; Pattanaik, A.; Anandan, M.; Blümmel, M. Food-feed crops research: A synthesis. Anim. Nutr. Feed Technol. 2010, 10S, $1-10$.

8. Roberts, C.; Stuth, J.; Finn, P. NIRS application in forage and feedstuffs. In Infrared Spectroscopy in Agriculture; Roberts, C., Workman, J., Reeves, J., Eds.; American Society of Agronomy: Madison, WI, USA, 2004.

9. Marten, G.; Shenk, J.; Barton, E. Near Infrared Reflectance Spectroscopy (NIRS): Analysis of Forage Quality; U.S. Department of Agriculture, 1989; pp. 20-38. Available online: https://naldc.nal.usda.gov/download/CAT89919964/PDF (accessed on 25 November 2021).

10. Evangelista, C.; Basiricò, L.; Bernabucci, U. An Overview on the Use of Near Infrared Spectroscopy (NIRS) on Farms for the Management of Dairy Cows. Agriculture 2021, 11, 296. [CrossRef]

11. Dereje, F.; Bediye, S.; Sileshi, Z. Characterizing and predicting chemical composition and in vitro digestibility of crop residue using near infrared reflectance spectroscopy (NIRS). Livest. Res. Rural Dev. 2010, 22, 29. Available online: http://www.lrrd.org/ lrrd22/2/feka22029.htm (accessed on 20 November 2021).

12. Shenk, J.S.; Westerhaus, M.O. Population Definition, Sample Selection, and Calibration Procedures for Near Infrared Reflectance Spectroscopy. Crop. Sci. 1991, 31, 469-474. [CrossRef]

13. AOAC. Official Methods of Analysis, 18th ed.; AOAC: Gaithersburg, MD, USA, 2006.

14. Van Soest, P.; Robertson, J.; Lewis, B. Methods for dietary fiber, neutral detergent fiber, and nonstarch polysaccharides in relation to animal nutrition. J. Dairy Sci. 1991, 74, 3583-3597. [CrossRef]

15. Menke, K.; Steingass, H. Estimation of the energy feed value obtained from chemical analysis and in vitro gas production using rumen fluid. Anim. Res. Dev. 1988, 28, 7-55.

16. Menke, K.; Raab, L.; Salewski, A.; Steingass, H.; Fritz, D.; Schneider, W. The estimation of the digestibility and metabolizable energy content of ruminant feedingstuffs from the gas production when they are incubated with rumen liquor in vitro. J. Agric. Sci. 1979, 93, 217-222. [CrossRef]

17. Bharadwaj, C.; Tripathi, S.; Soren, K.R.; Thudi, M.; Singh, R.K.; Sheoran, S.; Roorkiwal, M.; Patil, B.S.; Chitikineni, A.; Palakurthi, R.; et al. Introgression of "QTL-hotspot" region enhances drought tolerance and grain yield in three elite chickpea cultivars. Plant. Genome 2021, 14, e20076. [CrossRef] [PubMed]

18. Capper, B.; Thomson, E.; Herbert, F. Genetic Variation in the Feeding Value of Barley and Wheat Straw. In Proceedings of the Plant Breeding and the Nutritive Value of Crop Residues; Reed, J., Cappe, R., Neate, P., Eds.; ILRI: Addis Ababa, Ethiopia, 1988; pp. 177-192.

19. Reed, J.; Capper, B.; Neate, P. Plant Breeding and the Nutritive Value of Crop Residues; ILRI: Addis Ababa, Ethiopia, $1988 ;$ pp. 3-27.

20. Gronauer, A.; Heuwinkel, H.; Krapf, L.C.; Schmidhalter, U. Near Infrared Spectroscopy Calibrations for the Estimation of Process Parameters of Anaerobic Digestion of Energy Crops and Livestock Residues. J. Near Infrared Spectrosc. 2011, 19, 479-493.

21. Bruno-Soares, A.M.; Murray, I.; Paterson, R.M.; Abreu, J.M.F. Use of near infrared reflectance spectroscopy (NIRS) for the prediction of the chemical composition and nutritional attributes of green crop cereals. Anim. Feed Sci. Technol. 1998, 75, 15-25. [CrossRef]

22. Adesogan, A.T.; Owen, E.; Givens, D.I. Prediction of the in vivo digestibility of whole crop wheat from in vitro digestibility, chemical composition, in situ rumen degradability, in vitro gas production and near infrared reflectance spectroscopy. Anim. Feed Sci. Technol. 1998, 74, 259-272. [CrossRef]

23. Almendingen, K.; Meltzer, H.M.; Pedersen, J.I.; Nilsen, B.N.; Ellekjær, M. Near infrared spectroscopy-A potentially useful method for rapid determination of fat and protein content in homogenized diets. Eur. J. Clin. Nutr. 2000, 54, 20-23. [CrossRef]

24. Norris, K.H.; Barnes, R.F.; Moore, J.E.; Shenk, J.S. Predicting Forage Quality by Infrared Replectance Spectroscopy. J. Anim. Sci. 1976, 43, 889-897. [CrossRef]

25. Marten, G.C.; Halgerson, J.L.; Cherney, J.H. Quality Prediction of Small Grain Forages by Near Infrared Reflectance Spectroscopy 1. Crop. Sci. 1983, 23, 94-96. [CrossRef]

26. Mentink, R.L.; Hoffman, P.C.; Bauman, L.M. Utility of Near-Infrared Reflectance Spectroscopy to Predict Nutrient Composition and In Vitro Digestibility of Total Mixed Rations. J. Dairy Sci. 2006, 89, 2320-2326. [CrossRef]

27. Clark, D.H.; Mayland, H.F.; Lamb, R.C. Mineral Analysis of Forages with near Infrared Reflectance Spectroscopy 1. Agron. J. 1987, 79, 485-490. [CrossRef]

28. Büning-Pfaue, H. Analysis of water in food by near infrared spectroscopy. Food Chem. 2003, 82, 107-115. [CrossRef]

29. Begley, T.H.; Lanza, E.; Norris, K.H.; Hruschka, W.R. Determination of sodium chloride in meat by near-infrared diffuse reflectance spectroscopy. J. Agric. Food Chem. 1984, 32, 984-987. [CrossRef]

30. Goi, A.; Manuelian, C.L.; Currò, S.; Marchi, M. Prediction of Mineral Composition in Commercial Extruded Dry Dog Food by Near-Infrared Reflectance Spectroscopy. Anim. Open Access J. 2019, 9, 640. [CrossRef]

31. Manuelian, C.L.; Currò, S.; Penasa, M.; Cassandro, M.; De Marchi, M. Prediction of minerals, fatty acid composition and cholesterol content of commercial cheeses by near infrared transmittance spectroscopy. Int. Dairy J. 2017, 71, 107-113. [CrossRef] 
32. González-Martín, I.; Hernández-Hierro, J.M.; Revilla, I.; Vivar-Quintana, A.; Lobos Ortega, I. The mineral composition (Ca, P, $\mathrm{Mg}, \mathrm{K}, \mathrm{Na}$ ) in cheeses (cow's, ewe's and goat's) with different ripening times using near infrared spectroscopy with a fibre-optic probe. Food Chem. 2011, 127, 147-152. [CrossRef]

33. Boschetti, L.; Ottavian, M.; Facco, P.; Barolo, M.; Serva, L.; Balzan, S.; Novelli, E. A correlative study on data from pork carcass and processed meat (Bauernspeck) for automatic estimation of chemical parameters by means of near-infrared spectroscopy. Meat Sci. 2013, 95, 621-628. [CrossRef]

34. Prevolnik, M.; Škrlep, M.; Janeš, L.; Velikonja-Bolta, Š.; Škorjanc, D.; Čandek-Potokar-Potokar, M. Accuracy of near infrared spectroscopy for prediction of chemical composition, salt content and free amino acids in dry-cured ham. Meat Sci. 2011, 88, 299-304. [CrossRef] [PubMed]

35. De Marchi, M.; Manuelian, C.L.; Ton, S.; Manfrin, D.; Meneghesso, M.; Cassandro, M.; Penasa, M. Prediction of sodium content in commercial processed meat products using near infrared spectroscopy. Meat Sci. 2017, 125, 61-65. [CrossRef]

36. Lucas, A.; Andueza, L.; Rock, E.; Martin, B. Prediction of dry matter, fat, pH, vitamins, minerals, carotenoids, total antioxidant capacity, and color in fresh and freeze-dried cheeses by visible-near-infrared reflectance spectroscopy. J. Agric. Food Chem. 2008, 56, 6801-6808. [CrossRef] 